\title{
Appliance of a high pressure semi-batch reactor: supercritical transesterification of soybean oil using methanol
}

\author{
Wanessa Almeida da COSTA ${ }^{1,2}$, Fernanda Wariss Figueiredo BEZERRA ${ }^{2}$, Mozaniel Santana de OLIVEIRA ${ }^{2}$, \\ Marcilene Paiva da SILVA², Vânia Maria Borges CUNHA², Eloisa Helena de Aguiar ANDRADE², \\ Raul Nunes de CARVALHO JÚNIOR ${ }^{1,2 *}$
}

\begin{abstract}
This work presents the results of a supercritical transesterification process of soybean oil using methanol, performed in a laboratory high pressure semi-batch reactor. A full description of the equipment and a standard operating procedure are also provided. Since fossil fuels are not renewable, biofuels such biodiesel, have gained attention over the past decades. Biodiesel is the result of the transesterification of triacylglycerols in vegetable oils or animal fats and it works as an alternative fuel for compression-ignition engines. Methanol was chosen to perform the reaction, at molar ratios of 1:24 (oil: alcohol) and $0.1\left(\mathrm{CO}_{2}\right.$ :methanol), temperature of $280^{\circ} \mathrm{C}$ and pressure of 130 bar. In order to decrease the reaction time, $\mathrm{CO}_{2}$ in the supercritical state was used as cosolvent. The yield of biodiesel produced was equal to $95.19 \%$ in only ten minutes of reaction. A high yield of methyl esters (84.41\%) was detected by gas chromatography-mass spectrometry. In general, 10 compounds were identified. The component in higher concentration was linoleate, followed by methyl hexadecanoate, oleic acid methyl ester and methyl stearate. The ester conversion rate means that the process with supercritical methanol can be successfully applied to produce biodiesel.
\end{abstract}

Keywords: autoclave; transesterification; high-pressure reaction; supercritical conditions.

Practical Application: The development of new techniques is of great importance for the future generations, since the more the world population grows, the more energy is required to maintain life quality. This includes the production of biofuels, considering that fossil fuels are not renewable. Thus, to produce biodiesel, the supercritical transesterification corresponds to an alternative to the standard transesterification method since it does not require the use of conventional catalysts, generates less undesirable products, with a high rate of alkyl esters, in a short-time reaction.

\section{Introduction}

Nowadays, the need for renewable energy sources increases everyday due to the greater demand for petroleum products, which are not renewable and tends to be more expensive in the future. Another aspect of these products is that they produce a lot of harmful composites, such as carbon monoxide, nitrogen and sulfur oxides. Therefore, attention has been focused on developing renewable, biodegradable or alternative fuels, such as biodiesel to replace petroleum based fuels (Fukuda et al., 2001; Gopinath et al., 2009; Javidialesaadi \& Raeissi, 2013).

Biodiesel is the result of the transesterification of triacylglycerols in vegetable oils or animal fats. It works as an alternative fuel for compression-ignition engines. Since the transesterification reaction needs a short-chain alcohol, methanol and ethanol are the most used (Bunyakiat et al., 2006; Ali et al., 2013).

At first, the transesterification is a reversible reaction (Figure 1). However, the glycerol formed is immiscible in biodiesel, greatly reducing the extent of the reverse reaction.
The miscibility of glycerol in the biodiesel is a factor favoring the yield of reaction; however, the possibility of forming stable emulsions, in certain cases, may require a long period of rest for phase separation of biodiesel and glycerol (Atadashi et al., 2011; Lourenço \& Stradiotto, 2009).

In biodiesel production with base catalysts, besides the transesterification reactions, saponification of alkyl esters or of triacylglycerols themselves may also occur. Saponification is the formation of soap, i.e., salts of fatty acids, which can also occur due to a high content of free fatty acids in oils or fats. The soap formation involves three problems: it consumes the catalyst used in the reaction; it causes an increase in viscosity or formation of gels that interferes in the reaction. Also, the presence of soap in the reaction mixture stabilizes the biodiesel/glycerol emulsion. A technical problem is also related to the use of biodiesel with high soap content: engine damage due to fouling and corrosion (Van Gerpen, 2005; Ma \& Hanna, 1999; Meher et al., 2006).

${ }^{1}$ Programa de Pós-graduação em Engenharia de Recursos Naturais da Amazônia - PRODERNA, Instituto de Tecnologia - ITEC, Universidade Federal do Pará - UFPA,

${ }^{2}$ Laboratório de Extração - LABEX, Faculdade de Engenharia de Alimentos - FEA, Instituto de Tecnologia - ITEC, Universidade Federal do Pará - UFPA, Belém, PA, Brasil

${ }^{3}$ Laboratório Adolpho Ducke, Museu Paraense Emílio Goeldi, Belém, PA, Brasil

*Corresponding author: raulncj@ufpa.br 


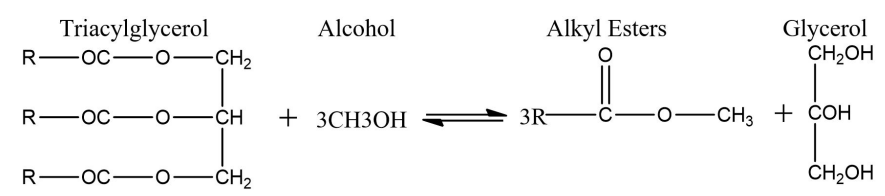

Figure 1. Overall scheme of a generic triacylglycerol transesterification with methanol.

The biodiesel production may involve the use of catalysts: acids but mostly bases (hydroxide or sodium alkoxide or potassium). It has the advantage of being carried out at room temperature and still be faster than the transesterification catalyzed by acids, which needs to be performed at elevated temperatures $\left(170^{\circ} \mathrm{C}\right)$ (Rinaldi et al., 2007; Vicente et al., 2004).

Many types of vegetable oils can be used to produce biodiesel. Sunflower, corn, olive, palm and soybean oils are good examples of raw materials that are widely used in this process. Since Brazil is a great producer of soybean, its oil is one of the most used as cooking oil, in the food industry and in the transesterification technique (Geris et al., 2007). In addition, its composition of fatty acids is well known, consisting mostly of linoleic, oleic and linolenic acids (Kawazoe, 2014).

Several authors, such as Bernardes et al. (2007), Antunes et al. (2008) and Li et al. (2012) have worked with transesterification of soybean oil, and obtained high conversion of fatty acid esters. In these works, methanol and/or ethanol as the reaction alcohol, as well as different kinds of catalysts were used, such as potassium hidroxyde, zinc oxide, aluminium oxide and even enzymes. Dealing exactly with transesterification of soybean oil with supercritical alcohol and carbon dioxide, the papers of Bertoldi et al. (2009) and Cheng et al. (2010) can be highlighted.

In addition to the conventional method of producing biodiesel, another technique has been investigated over the past few years: the supercritical transesterification process. This method has been studied by many authors such as Demirbas (2005), Varma et al. (2010), Sawangkeaw et al. (2011), Anikeev \& Yakovleva (2013), Tsai et al. (2013) and Ngamprasertsith et al. (2014). According to Marulanda (2012), this process has the advantage of promoting fast transesterification reactions of triacylglycerols and immediate esterification of free fatty acids without the excessive formation of glycerol and no need of a conventional catalyst. It also forms a homogeneous phase of the alcohol and triacylglycerols mixture.

The use of supercritical $\mathrm{CO}_{2}$ can affect the kinetic behavior of the transesterification reaction. This may occur due to the increase of alcohol solubility in the oil phase (Galia et al., 2011). It is reported that the methylation of fixed oils using supercritical fluids may be a viable alternative for the production of biodiesel from different plant matrices (Chen et al., 2010; Soh \& Zimmerman, 2011).

The type of reactor used in transesterification processes is also a very important factor to consider. Authors such as Spallina et al. (2017) and Gianotti Pret et al. (2015) worked with the design, modeling and validation of reactors. Mjalli et al. (2009) dealt with the developing and validation of a transesterification reactor. According to Kern \& Shastri (2015), this process can be carried out in a continuous or batch reactor, but the batch process is often preferred because of its flexibility and accommodation of various types of raw materials, composition, and quantity, thus making possible to satisfy specific product requirements. Lim \& Lee (2011) and Ghoreishi \& Moein (2013) also used batch reactors to transesterificate vegetable oils using methanol in supercritical conditions, obtaining high yields of fatty acid methyl esters.

In this context, the objective of this work was to evaluate the process of supercritical transesterification of soybean oil with methanol in the presence of carbon dioxide, and provide comparisons to the conventional technique.

\section{Materials and methods}

\subsection{Equipment description}

The supercritical transesterification reaction of soybean oil with methanol and $\mathrm{CO}_{2}$ was performed in a stainless-steel autoclave (model 2777 1000, Top Industrie, France) with internal volume of $0.095 \mathrm{~L}(0.128 \times 0.152 \mathrm{~m})$. To the autoclave were attached a heating collar (model 2777 1021, Top Industrie, France), a magnetic stirrer (model 616 0100, Top Industrie, FR), a cooling bath (model Q214U2, Quimis, Brazil), a thermocouple TKA 15 x 20 HMP, Erciat, France), a safety head (model 7280350 , Top Industrie, France), a rupture disk (model 7280400 , Sitec, Switzerland), a pressure transducer (model PA-Keller, Switzerland), a $\mathrm{CO}_{2}$ supply system, a sample collection system with approximately $8 \mathrm{~mL}$, and a control panel (model TS1070, Monitouch Technoshot, The Netherlands). More details are in the Appendix A at the end of the references section.

\subsection{Materials}

For the transesterification process, commercial refined soybean oil (LISA, Brazil), obtained in a supermarket in Belem/Para/Brazil was used as the vegetable oil. The alcohol used was Methanol (99.9\% purity, TEDIA, USA). The cosolvent used was carbon dioxide (99.9\% purity, White Martins, Brazil).

\subsection{Transesterification method}

The transesterification reaction of soybean oil with methanol and supercritical $\mathrm{CO}_{2}$ is represented in the system shown in Figure 2. For the study, the operating conditions were those used in the paper of Han et al. (2005), who also dealt with the supercritical transesterification of soybean oil using methanol. Molar ratios of 1:24 (oil:alcohol) and $0.1\left(\mathrm{CO}_{2}\right.$ to methanol), rotation of $700 \mathrm{rpm}$, pressure of $130 \mathrm{bar}$, temperature of $280^{\circ} \mathrm{C}$ and heating rate of approximately $4{ }^{\circ} \mathrm{C} / \mathrm{min}$ were used. After stabilization of the selected temperature and pressure, the $\mathrm{CO}_{2}$ inlet valve was opened so that there was no influence of temperature on the system pressure (autogenous pressure). After the reaction time (10 minutes), the sample (Figure 3) was collected and centrifuged (Multifuge X1R-N/S 41464410, ThermoElectron Led GMBH, USA) at 10,000 rpm for 15 minutes to separate the water and glycerin formed. 


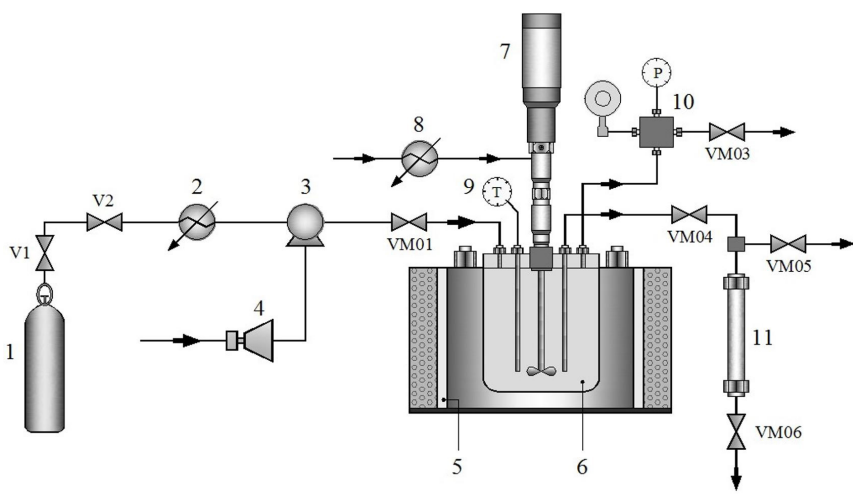

Figure 2. Schematic representation of the system used for methanolic transesterification of soybean oil. 1. $\mathrm{CO}_{2}$ tank; 2. Cooling bath; 3. Pump; 4. Compressor; 5 . Heating collar; 6. Autoclave; 7. Magnetic stirrer; 8. Cooling bath; 9. Thermocouple; 10. Safety head and rupture disc; 11. Sampler; V1-V2/VM01-VM06 Flow control valves. Described by Bezerra et al. (2018).

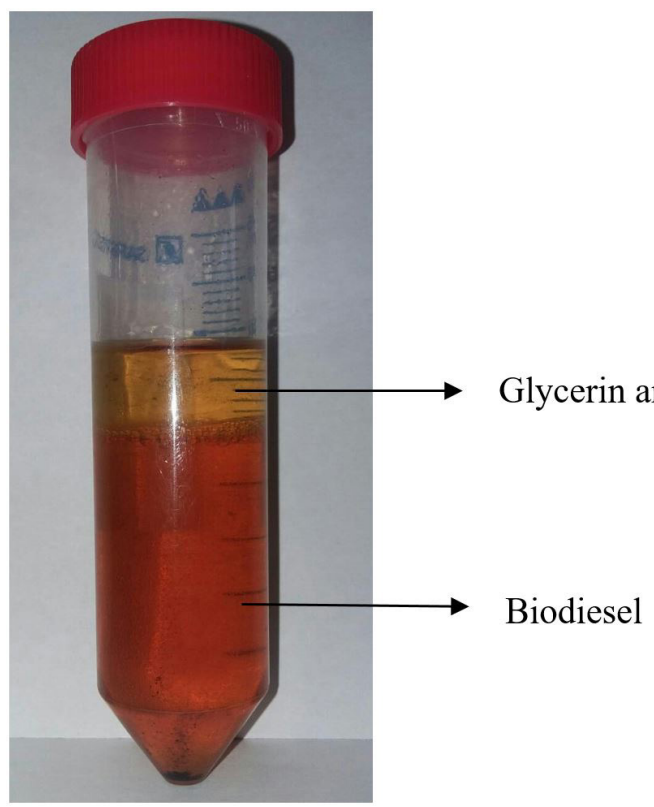

Figure 3. Sample obtained by supercritical transesterification of soybean oil with methanol and $\mathrm{CO}_{2}$.

\subsection{Analysis of the methyl esters obtained}

The fatty acid methyl esters were analyzed as described in the literature (Xavier et al., 2011) by gas chromatography-mass spectrometry (GC-MS),using a QP 2010 Shimadzu system equipped with an AOC-20i auto injector, Rtx-5MS silica capillary column ( $30 \mathrm{~m} \mathrm{x} 0.25 \mathrm{~mm}$, film thickness of $0.25 \mu \mathrm{m}$ ) at temperatures ranging from $100{ }^{\circ} \mathrm{C}$ to $280{ }^{\circ} \mathrm{C}$, with a gradient of $4{ }^{\circ} \mathrm{C} / \mathrm{min}$ and injector temperature of $100^{\circ} \mathrm{C}$; helium as carrier gas at a flow rate of $1.2 \mathrm{~mL} / \mathrm{min}$ (measured at $100^{\circ} \mathrm{C}$ ), The injector was of splitless injection, with $0.1 \mu \mathrm{L}$ of a transesterified solution; programmed temperature of $100{ }^{\circ} \mathrm{C}-280^{\circ} \mathrm{C}$ with a gradient of $5{ }^{\circ} \mathrm{C} / \mathrm{min}$. The quadrupole filter scanned from 39 to 550 Daltons once every second. The ionization was acquired by the electron impact technique with energy of $70 \mathrm{eV}$. Each chemical component was identified by comparing their mass spectra with those in the literature (Adams, 2007) and on the NIST database (Stein, 2011).

\subsection{Yield of biodiesel production}

The yield of biodiesel production was calculated (Equation 1) based on the fatty acid methyl esters (FAME) analyzed by GC (Baroutian et al., 2010).

Yield $(\%)=\frac{A \times B}{C} \times 100$

Where: $A$ is mass of biodiesel produced; $B$ is total mass $\%$ of FAME; and $C$ is mass of oil used in the reaction.

\section{Results and discussion}

\subsection{Comparison to other studies on supercritical transesterification}

Table 1 presents some published works on transesterification by supercritical method.

The novelty of this work is in the equipment assembly. In fact, it was specifically made with certain specifications required by the authors, for example, inlet and outlet valves for supercritical $\mathrm{CO}_{2}$, a sampling valve, volume of the autoclave and the maximum pressure and temperature conditions that the reactor would withstand. None of the studies mentioned in Table 1 dealt with the assembly of the reactor used in their respective works. Therefore, the apparatus employed in our research is not a serial device but an exclusive equipment tailored to the authors's needs. The best conditions of pressure, temperature and molar ratio and the advantages of using methanol were considered from the study of Cao et al. (2005), which was the main paper we made comparisons with.

\subsection{Influence of molar ratio}

Molar ratio of alcohol to oil is one of the most significant factors that affect the conversion efficiency, yield of biodiesel and production cost (Musa, 2016). Since transesterification is an equilibrium reaction, the excess of methanol was used in order to shift the equilibrium to the right and produce more methyl esters as result of the reaction. Higher molar ratios of methanol to oil also result in a more efficient transesterification reaction, due to the increased contact area between methanol and triacylglycerols (Cao et al., 2005).

Some authors such as Van Kasteren \& Nisworo (2007), Baroutian et al. (2010) and Wang et al. (2012) conducted the transesterification reactions using excess alcohol and molar ratio of methanol to oil of 24:1, which was the same proportion used in this work. At this ratio, all of them presented high yields of biodiesel produced (over 90\%).

\subsection{Yield of fatty acids methyl esters}

In Figure 3 , it's possible to see the result of the transesterification process, with a low amount of wastewater and glycerin. The biodiesel yield obtained (Equation 1) was high and equal to $95.19 \%$, which 
Table 1. Studies on the transesterification by supercritical method.

\begin{tabular}{cccccccc}
\hline Oil & Solvent & $\mathrm{T}\left({ }^{\circ} \mathrm{C}\right)$ & $\mathrm{P}(\mathrm{bar})$ & $\tau(\mathrm{min})$ & $\mathrm{MR}$ & $\mathrm{Y}(\%)$ & References \\
\hline Soybean & Methanol & 280 & 128 & 10 & $24: 1$ & 98.00 & Cao et al. (2005) \\
Soybean & Methanol & 320 & 320 & 75 & $43: 1$ & 87.50 & Palacios-Nereo et al. (2016) \\
Castor & Methanol & 300 & 210 & 90 & $43: 1$ & 96.50 & Román-Figueroa et al. (2016) \\
Soybean & $\mathrm{CO}_{2}$ & 85 & 80 & 60 & - & 92.00 & Hu et al. (2015) \\
Rapeseed & Ethanol & 350 & 120 & 20 & $42: 1$ & 91.90 & Micic et al. (2014) \\
Castor & Ethanol & 350 & 145 & 10 & $40: 1$ & 56.20 & Rodríguez-Guerrero et al. (2013) \\
Soybean & Methanol & 320 & 200 & 40 & $45: 1$ & 92.30 & Shin et al. (2013) \\
Turnip & Ethanol & 319 & 110 & 22 & $39: 1$ & 97.50 & Valle et al. (2010) \\
Soybean & Methanol & 350 & 150 & 12,5 & $40: 1$ & 91.40 & Wang et al. (2008) \\
Soybean & Methanol & 280 & 143 & 10 & $24: 1$ & 98.00 & Han et al. (2005) \\
\hline
\end{tabular}

T: temperature; P: pressure; $\tau$ : time; MR: molar ratio; Y: esters yield.

was close to the results found in the literature. Han et al. (2005) obtained a biodiesel yield of $98 \%$, using the same raw material and operating conditions of this study. Palacios-Nereo et al. (2016) also performed the supercritical transesterification of soybean oil using methanol. They reached yield of $99.9 \%$, at molar ratio $1: 42$ (oil:methanol), applying gradual heating $\left(0.51^{\circ} \mathrm{C} / \mathrm{min}\right)$, starting from $150^{\circ} \mathrm{C}$ up to $320^{\circ} \mathrm{C}$ and maintaining this temperature for 10 minutes. They found out that this hybrid process prevented the reactions of thermal decomposition while transforming all triacylglycerols into biodiesel.

According to Shin et al. (2013), in the supercritical transesterification reaction, the purification of products is much simpler, since low amount of unwanted compounds is generated, and high biodiesel yield is reached in a very short time. Thus, the technique with supercritical methanol is considered more economically viable than the use of conventional catalytic reactions.

Regarding the rate of methyl ester conversion, in the sample of oil transesterified with methanol, it is observed (Table 2) that the highest concentration is of linoleate, followed by methyl hexadecanoate, oleic acid methyl ester and methyl stearate with $41.92 \%, 18.07 \%, 7.67 \%$ and $7.2 \%$, respectively. In general, 10 compounds were identified; together they represent $81.41 \%$ of the components present after the transesterification of the soybean oil.

In recent article, regarding production of biodiesel from vegetable matrix, Xavier et al. (2011) obtained the compounds methyl hexadecanoate (32\%), methyl octadecanoate (29\%) and methyl (E)-octadecanoate (29\%) of Caryocar villosum (Aubl.) Pers, in higher concentration after the synthesis with methanol, under normal conditions of temperature and pressure. Of these components, only methyl hexadecanoate was identified in the present work in a lower concentration.

\subsection{Comparison to the conventional transesterification method}

Wu et al. (2013) performed the conventional transesterification process of soybean oil using methanol and $\mathrm{CaO} / \mathrm{NaY}$ catalyst. They obtained biodiesel yield of $95 \%$ with 30 wt.\% of $\mathrm{CaO}$ loaded on $\mathrm{NaY}$ zeolite, molar ratio 1:9 (soybean oil:methanol), temperature of $65^{\circ} \mathrm{C}$, time of $3 \mathrm{~h}$ and catalyst/oil mass ratio of $3 \%$. Liu et al. (2008) also dealt with biodiesel production from
Table 2. Fatty acid methyl esters identified in the transesterified product. Composition obtained by gas chromatography coupled to mass spectrometry.

\begin{tabular}{cccc}
\hline $\mathrm{RT}(\mathrm{min})^{*}$ & $\mathrm{RI}^{* *}$ & Fatty acid methyl esters & wt $(\%)$ \\
\hline $\mathbf{5 . 3 2 5}$ & 1114 & Methyl octanoate & 1.22 \\
$\mathbf{1 1 . 0 0 0}$ & 1323 & Decadienal $<2 \mathrm{E}, 4 \mathrm{E}->$ & 0.62 \\
$\mathbf{2 6 . 2 5 8}$ & 1725 & Tetradecanoate $<$ methyl-> & 1.12 \\
$\mathbf{3 4 . 0 1 7}$ & 1945 & Methyl hexadecanoate & 19.07 \\
$\mathbf{3 5 . 4 6 7}$ & 1989 & Hexadecanoicacid $<\mathrm{n}-$ & 0.02 \\
$\mathbf{3 9 . 1 0 0}$ & 2102 & Linoleate $<$ methyl-> & 41.92 \\
$\mathbf{4 0 . 3 2 5}$ & 2141 & Oleic acid methyl ester & 7.67 \\
$\mathbf{4 0 . 6 7 5}$ & 2153 & Methyl stearate & 7.2 \\
$\mathbf{4 5 . 1 8 3}$ & 2303 & 11-Eicosenoic acid, methyl ester & 1.27 \\
$\mathbf{5 1 . 4 8 3}$ & 2531 & Docosanoate $<$ methyl-> & 1.3 \\
Total & & & 81.41 \\
\hline
\end{tabular}

${ }^{\star}$ RT: Retention time; ${ }^{* *}$ RI: Retention Index.

soybean oil and methanol, using $\mathrm{CaO}$ as a solid base catalyst. Assays at molar ratio 12:1 (methanol to oil), addition of $8 \% \mathrm{CaO}$, and $65^{\circ} \mathrm{C}$ gave the best results (over 95\%), in $3 \mathrm{~h}$.

In both studies, the biodiesel yield obtained was close to that reached in this work. Despite the fact that lower reaction temperatures and molar ratios were necessary, with no need of increasing pressure, they had to use base catalysts and reaction time was quite superior to that applied in this study. Also, fewer residues are generated, and the product purification is performed in fewer steps. However, it cannot be said that the supercritical transesterification is economically viable compared to the conventional technique, due to energy and equipment costs are higher than those observed in a conventional process. Thus, a comparative economic analysis is necessary.

\subsection{Influence of the reactor type used in the transesterification process}

Silva \& Oliveira (2014) state that the biodiesel production under supercritical conditions requires high processing costs (high molar ratios, pressures and temperatures) and some strategies to reduce the expected high operating costs usually involve the addition of cosolvents and the use of different reactor configurations with increased mass transfer, operating 
in continuous mode (microreactor or packed bed reactor). Many authors such as Pohar \& Plazl (2008), Hessel et al. (2005), Wen et al. (2009) recommend to conduct transesterification reactions in microreactors in order to reduce the limitations of mass and heat transfer, since such parameters tend to increase due to the small size and large contact area (Pohar \& Plazl, 2008), and the small internal diameters (typically $10-300 \mu \mathrm{m}$ ) promote interaction with the reagents at molecular level. In the case of the reactor used in this study, its internal diameter $(51 \mathrm{~mm})$ and volume $(0.095 \mathrm{~L})$ represent the most suitable configuration, which was verified by the high biodiesel yield obtained (95.19\%).

Comparing to other studies, Wang et al. (2008), for example, used a continuous tubular reactor with no mechanical blending to perform the transesterification reaction of soybean oil with methanol under supercritical conditions. Thus, in order to increase the biodiesel yield, they had to acidify the soybean oil by adding a certain amount of organic into the reaction system. At the molar ratio of 1:20 (oil:methanol), the biodiesel yield of acidified oil, and non-acidified oil were 82.3 and 60.0\%, respectively.

\section{Conclusion}

The reactor used in this study proved to be efficient for the transesterification process. The reaction time was only 10 minutes, under experimental conditions of $130 \mathrm{bar}, 280^{\circ} \mathrm{C}$ and molar ratio of raw material to methanol of $1: 24$, and $\mathrm{CO}_{2}$ to methanol of 0.1. The yield of biodiesel was $95.19 \%$ and the yield of methyl esters was $81.41 \%$, with linoleate being the compound found in the highest concentration. The results indicate that the undesirable compounds glycerin and wastewater were obtained in low concentrations, which means that this method can be applied to obtain biodiesel with no need of base catalysts and fewer steps of purification compared to the conventional method.

\section{Acknowledgements}

Wanessa Almeida da Costa (1427204/2014), Fernanda Wariss Figueiredo Bezerra (1718822/2017), Mozaniel Santana de Oliveira (1662230/2016), Marcilene Paiva da Silva (1636612/2016), and Vânia Maria Borges Cunha (1566277/2015) thank CAPES for the scholarship. The authors thank FAPESPA (ICCAF: 134/2014).

\section{References}

Adams, R. P. (2007). Identification of essential oil components by gas chromatography/mass spectroscopy (4th ed.). Carol Stream: Allured Publishing Corporation.

Ali, M. H., Mashud, M., Rubel, M. R., \& Ahmad, R. H. (2013). Biodiesel from Neem oil as an alternative fuel for Diesel engine. Procedia Engineering, 56, 625-630. http://dx.doi.org/10.1016/j. proeng.2013.03.169.

Anikeev, V. I., \& Yakovleva, E. Y. (2013). Biodiesel synthesis from vegetable oils with supercritical methanol. The Journal of Supercritical Fluids, 77, 100-102. http://dx.doi.org/10.1016/j.supflu.2013.02.018.

Antunes, W. M., Oliveira Veloso, C., \& Henriques, C. A. (2008). Transesterification of soybean oil with methanol catalyzed by basic solids. Catalysis Today, 133, 548-554. http://dx.doi.org/10.1016/j. cattod.2007.12.055.
Atadashi, I. M., Aroua, M. K., \& Aziz, A. A. (2011). Biodiesel separation and purification: a review. Renewable Energy, 36(2), 437-443. http:// dx.doi.org/10.1016/j.renene.2010.07.019.

Baroutian, S., Aroua, M. K., Raman, A. A. A., \& Sulaiman, N. M. N. (2010). Potassium hydroxide catalyst supported on palm shell activated carbon for transesterification of palm oil. Fuel Processing Technology, 91(11), 1378-1385. http://dx.doi.org/10.1016/j.fuproc.2010.05.009.

Bernardes, O. L., Bevilaqua, J. V., Leal, M. C., Freire, D. M., \& Langone, M. A. (2007). Biodiesel fuel production by the transesterification reaction of soybean oil using immobilized lipase. Applied Biochemistry and Biotecnology, 137(1-12), 105-114.

Bertoldi, C., da Silva, C., Bernardon, J. P., Corazza, M. L., Cardoso, L. Fo., Oliveira, J. V., \& Corazza, F. C. (2009). Continuous production of biodiesel from soybean oil in supercritical ethanol and carbon dioxide as cosolvent. Energy \& Fuels, 23(10), 5165-5172. http:// dx.doi.org/10.1021/ef900402r.

Bezerra, F. W. F., Costa, W. A., Oliveira, M. S., Aguiar Andrade, E. H., \& Carvalho, R. N. Jr. (2018). Transesterification of palm pressed-fibers (Elaeis guineensis Jacq.) oil by supercritical fluid carbon dioxide with entrainer ethanol. The Journal of Supercritical Fluids, 136, 136-143. http://dx.doi.org/10.1016/j.supflu.2018.02.020.

Bunyakiat, K., Makmee, S., Sawangkeaw, R., \& Ngamprasertsith, S. (2006). Continuous production of biodiesel via transesterification from vegetable oils in supercritical methanol. Energy \& Fuels, 20(2), 812-817. http://dx.doi.org/10.1021/ef050329b.

Cao, W., Han, H., \& Zhang, J. (2005). Preparation of biodiesel from soybean oil using supercritical methanol and co-solvent. Fuel, 84(4), 347-351. http://dx.doi.org/10.1016/j.fuel.2004.10.001.

Chen, C. H., Chen, W. H., Chang, C. M. J., Lai, S. M., \& Tu, C. H. (2010). Biodiesel production from supercritical carbon dioxide extracted Jatropha oil using subcritical hydrolysis and supercritical methylation. The Journal of Supercritical Fluids, 52(2), 228-234. http://dx.doi.org/10.1016/j.supflu.2009.12.010.

Cheng, Z., Cunwen, W., Weiguo, W. A. N. G., Yuanxin, W. U., \& Faquan, Y. U. (2010). Continuous production of biodiesel from soybean oil using supercritical methanol in a vertical tubular reactor: I. Phase holdup and distribution of intermediate product along the axial direction. Chinese Journal of Chemical Engineering, 18(4), 626-629. http://dx.doi.org/10.1016/S1004-9541(10)60266-2.

Demirbas, A. (2005). Biodiesel production from vegetable oils via catalytic and non-catalytic supercritical methanol transesterification methods. Progress in Energy and Combustion Science, 31(5-6), 466487. https://doi.org/10.1016/j.pecs.2005.09.001.

Fukuda, H., Kondo, A., \& Noda, H. (2001). Biodiesel fuel production by transesterification of oils. Journal of Bioscience and Bioengineering, 92(5), 405-416. http://dx.doi.org/10.1016/S1389-1723(01)80288-7. PMid:16233120.

Galia, A., Scialdone, O., \& Tortorici, E. (2011). Transesterification of rapeseed oil over acid resins promoted by supercritical carbon dioxide. The Journal of Supercritical Fluids, 56(2), 186-193. http:// dx.doi.org/10.1016/j.supflu.2010.12.005.

Geris, R., Santos, N. A. C., Amaral, B. A., Maia, I. S., Castro, V. D., \& Carvalho, J. R. M. (2007). Biodiesel from soybean oil: experimental procedure of transesterification for organic chemistry laboratories. Química Nova, 30(5), 1369-1373. http://dx.doi.org/10.1590/S010040422007000500053.

Ghoreishi, S. M., \& Moein, P. (2013). Biodiesel synthesis from waste vegetable oil via transesterification reaction in supercritical methanol. The Journal of Supercritical Fluids, 76, 24-31. http://dx.doi. org/10.1016/j.supflu.2013.01.011. 
Gianotti Pret, M., Ferrero, D., Lanzini, A., \& Santarelli, M. (2015). Thermal design, modeling and validation of a steam-reforming reactor for fuel cell applications. Chemical Engineering Research \& Design, 104, 503-512. http://dx.doi.org/10.1016/j.cherd.2015.09.016.

Gopinath, A., Puhan, S., \& Nagarajan, G. (2009). Theoretical modeling of iodine value and saponification value of biodiesel fuels from their fatty acid composition. Renewable Energy, 34(7), 1806-1811. http:// dx.doi.org/10.1016/j.renene.2008.11.023.

Han, H., Cao, W., \& Zhang, J. (2005). Preparation of biodiesel from soybean oil using supercritical methanol and CO 2 as co-solvent. Process Biochemistry, 40(9), 3148-3151. http://dx.doi.org/10.1016/j. procbio.2005.03.014.

Hessel, V., Löwe, H., Müller, A., \& Kolb, G. (2005). Chemical micro process engineering: fundamentals, modelling and reactions. Germany: Wiley-VCH Verlag. http://dx.doi.org/10.1002/3527603581.

Hu, L., Llibin, S., Li, J., Qi, L., Zhang, X., Yu, D., Walid, E., \& Jiang, L. (2015). Lipase-catalyzed transesterification of soybean oil and phytosterol in supercritical CO 2. Bioprocess and Biosystems Engineering, 38(12), 2343-2347. http://dx.doi.org/10.1007/s00449015-1469-5. PMid:26386863.

Javidialesaadi, A., \& Raeissi, S. (2013). Biodiesel production from high free fatty acid-content oils: experimental investigation of the pretreatment step. APCBEE Procedia, 5, 474-478. http://dx.doi. org/10.1016/j.apcbee.2013.05.080.

Kawazoe, L. (2014). Dossiê óleos: óleos. Food Ingredientes Brasil, 31, 38-55.

Kern, R., \& Shastri, Y. (2015). Advanced control with parameter estimation of batch transesterification reactor. Journal of Process Control, 33, 127-139. http://dx.doi.org/10.1016/j.jprocont.2015.06.006.

Le Bureau de Normalisation - LBN. (2000). NF EN 10272: Barres en acier inoxydable pour appareils à pression (Indice de classement: A36-225). Bruxelles: LBN.

Le Bureau de Normalisation - LBN. (2013). NF EN 10269: Aciers et alliages de nickel pour éléments de fixation utilisés à température élevée et/ou basse température (Indice de classement: A35-558). Bruxelles: LBN.

Li, Y., Qiu, F., Yang, D., Sun, P., \& Li, X. (2012). Transesterification of soybean oil and analysis of bioproduct. Food and Bioproducts Processing, 90(2), 135-140. http://dx.doi.org/10.1016/j.fbp.2011.02.004.

Lim, S., \& Lee, K. T. (2011). Effects of solid pre-treatment towards optimizing supercritical methanol extraction and transesterification of Jatropha curcas L. seeds for the production of biodiesel. Separation and Purification Technology, 81(3), 363-370. http://dx.doi.org/10.1016/j. seppur.2011.08.003.

Liu, X., He, H., Wang, Y., Zhu, S., \& Piao, X. (2008). Transesterification of soybean oil to biodiesel using $\mathrm{CaO}$ as a solid base catalyst. Fuel, 87(2), 216-221. https://doi.org/10.1016/j.fuel.2007.04.013.

Lourenço, L. M., \& Stradiotto, N. R. (2009). Determination of free glycerol in biodiesel at a platinum oxide surface using potential cycling technique. Talanta, 79(1), 92-96. http://dx.doi.org/10.1016/j. talanta.2009.03.013. PMid:19376349.

Ma, F., \& Hanna, M. A. (1999). Biodiesel production: a review. Bioresource Technology, 70(1), 1-15. http://dx.doi.org/10.1016/ S0960-8524(99)00025-5.

Marulanda, V. F. (2012). Biodiesel production by supercritical methanol transesterification: process simulation and potential environmental impact assessment. Journal of Cleaner Production, 33, 109-116. http:// dx.doi.org/10.1016/j.jclepro.2012.04.022.

Meher, L., Vidyasagar, D., \& Naik, S. (2006). Technical aspects of biodiesel production by transesterification-a review. Renewable
\& Sustainable Energy Reviews, 10(3), 248-268. http://dx.doi. org/10.1016/j.rser.2004.09.002.

Micic, R. D., Tomić, M. D., Kiss, F. E., Nikolić-Djorić, E. B., \& Simikić, M. Đ. (2014). Influence of reaction conditions and type of alcohol on biodiesel yields and process economics of supercritical transesterification. Energy Conversion and Management, 86, 717-726. http://dx.doi.org/10.1016/j.enconman.2014.06.052.

Mjalli, F. S., Kim San, L., Chai Yin, K., \& Azlan Hussain, M. (2009). Dynamics and control of a biodiesel transesterification reactor. Chemical Engineering \& Technology, 32(1), 13-26. http://dx.doi. org/10.1002/ceat.200800243.

Musa, I. A. (2016). The effects of alcohol to oil molar ratios and the type of alcohol on biodiesel production using transesterification process. Egyptian Journal of Petroleum, 25(1), 21-31. http://dx.doi. org/10.1016/j.ejpe.2015.06.007.

Ngamprasertsith, S., Laetoheem, C. E., \& Sawangkeaw, R. (2014). Continuous production of biodiesel in supercritical ethanol: a comparative study between refined and used palm olein oils as feedstocks. Journal of the Brazilian Chemical Society, 25(9), 1746-1753.

Palacios-Nereo, F. J., Olivares-Carrillo, P., Pérez de los Ríos, A., \& Quesada-Medina, J. (2016). High-yield non-catalytic supercritical transesterification of soybean oil to biodiesel induced by gradual heating in a batch reactor. The Journal of Supercritical Fluids, 111, 135-142. http://dx.doi.org/10.1016/j.supflu.2016.01.022.

Pohar, A., \& Plazl, I. (2008). Laminar to turbulent transition and heat transfer in a microreactor: Mathematical modeling and experiments. Industrial \& Engineering Chemistry Research, 47(19), 7447-7455. http://dx.doi.org/10.1021/ie8001765.

Pressure Equipment Directive - EU. (1997). Guidelines related to the Pressure Equipment Directive 97/23/EC (PED). Brussels: EC.

Rinaldi, R., Garcia, C., Marciniuk, L. L., Rossi, A. V., \& Schuchardt, U. (2007). Síntese de biodiesel: uma proposta contextualizada de experimento para laboratório de química geral. Quimica Nova, 30(5), 1374-1380. http://dx.doi.org/10.1590/S0100-40422007000500054.

Rodríguez-Guerrero, J. K., Rubens, M. F., \& Rosa, P. T. V. (2013). Production of biodiesel from castor oil using sub and supercritical ethanol: effect of sodium hydroxide on the ethyl ester production. The Journal of Supercritical Fluids, 83, 124-132. http://dx.doi. org/10.1016/j.supflu.2013.08.016.

Román-Figueroa, C., Olivares-Carrillo, P., Paneque, M., Palacios-Nereo, F. J., \& Quesada-Medina, J. (2016). High-yield production of biodiesel by non-catalytic supercritical methanol transesterification of crude castor oil (Ricinus communis). Energy, 107, 165-171. http://dx.doi. org/10.1016/j.energy.2016.03.136.

Sawangkeaw, R., Bunyakiat, K., \& Ngamprasertsith, S. (2011). Continuous production of biodiesel with supercritical methanol: optimization of a scale-up plug flow reactor by response surface methodology. Fuel Processing Technology, 92(12), 2285-2292. http://dx.doi.org/10.1016/j. fuproc.2011.07.014.

Shin, H. Y., Ryu, J. H., Bae, S. Y., \& Kim, Y. C. (2013). Biodiesel production from highly unsaturated feedstock via simultaneous transesterification and partial hydrogenation in supercritical methanol. The Journal of Supercritical Fluids, 82, 251-255. http://dx.doi.org/10.1016/j. supflu.2013.08.004.

Silva, C. D., \& Oliveira, J. V. (2014). Biodiesel production through non-catalytic supercritical transesterification: current state and perspectives. Brazilian Journal of Chemical Engineering, 31(2), 271-285. http://dx.doi.org/10.1590/0104-6632.20140312s00002616. 
Soh, L., \& Zimmerman, J. (2011). Biodiesel production: the potential of algal lipids extracted with supercritical carbon dioxide. Green Chemistry, 13(6), 1422-1429. http://dx.doi.org/10.1039/c1gc15068e.

Spallina, V., Marinello, B., Gallucci, F., Romano, M. C., \& Van Sint Annaland, M. (2017). Chemical looping reforming in packed-bed reactors: modelling, experimental validation and large-scale reactor design. Fuel Processing Technology, 156, 156-170. http://dx.doi. org/10.1016/j.fuproc.2016.10.014.

Stein, S. E. (2011). NIST 11 mass spectral library: v 2.0. NIST/EPA/ NIH Mass Spectral Library and NIST Mass Spectral Search Program. Gaithersburg: NIST.

Tsai, Y. T., Lin, H. M., \& Lee, M. J. (2013). Biodiesel production with continuous supercritical process: non-catalytic transesterification and esterification with or without carbon dioxide. Bioresource Technology, 145, 362-369. http://dx.doi.org/10.1016/j.biortech.2012.12.157. PMid:23339904.

Valle, P., Velez, A., Hegel, P., Mabe, G., \& Brignole, E. A. (2010). Biodiesel production using supercritical alcohols with a non-edible vegetable oil in a batch reactor. The Journal of Supercritical Fluids, 54(1), 61-70. http://dx.doi.org/10.1016/j.supflu.2010.03.009.

Van Gerpen, J. (2005). Biodiesel processing and production. Fuel Processing Technology, 86(10), 1097-1107. http://dx.doi.org/10.1016/j. fuproc.2004.11.005.

Van Kasteren, J. M. N., \& Nisworo, A. P. (2007). A process model to estimate the cost of industrial scale biodiesel production from waste cooking oil by supercritical transesterification. Resources, Conservation and Recycling, 50(4), 442-458. http://dx.doi.org/10.1016/j. resconrec.2006.07.005.
Varma, M. N., Deshpande, P. A., \& Madras, G. (2010). Synthesis of biodiesel in supercritical alcohols and supercritical carbon dioxide. Fuel, 89(7), 1641-1646. http://dx.doi.org/10.1016/j.fuel.2009.08.012.

Vicente, G., Martınez, M., \& Aracil, J. (2004). Integrated biodiesel production: a comparison of different homogeneous catalysts systems. Bioresource Technology, 92(3), 297-305. http://dx.doi.org/10.1016/j. biortech.2003.08.014. PMid:14766164.

Wang, C. W., Zhou, J. F., Chen, W., Wang, W. G., Wu, Y. X., Zhang, J. F., Chi, R.-A., \& Ying, W.-Y. (2008). Effect of weak acids as a catalyst on the transesterification of soybean oil in supercritical methanol. Energy \& Fuels, 22(5), 3479-3483. http://dx.doi.org/10.1021/ef800121c.

Wang, J. X., Chen, K. T., Wen, B. Z., Liao, Y. H. B., \& Chen, C. C. (2012). Transesterification of soybean oil to biodiesel using cement as a solid base catalyst. Journal of the Taiwan Institute of Chemical Engineers, 43(2), 215-219. http://dx.doi.org/10.1016/j.jtice.2011.08.002.

Wen, Z., Yu, X., Tu, S. T., Yan, J., \& Dahlquist, E. (2009). Intensification of biodiesel synthesis using zigzag micro-channel reactors. Bioresource Technology, 100(12), 3054-3060. http://dx.doi.org/10.1016/j. biortech.2009.01.022. PMid:19230652.

Wu, H., Zhang, J., Wei, Q., Zheng, J., \& Zhang, J. (2013). Transesterification of soybean oil to biodiesel using zeolite supported $\mathrm{CaO}$ as strong base catalysts. Fuel Processing Technology, 109, 13-18. http://dx.doi. org/10.1016/j.fuproc.2012.09.032.

Xavier, W. K. S., Medeiros, B. J., Lima, C. S., Favacho, H. A., Aguiar Andrade, E. H., Neyva, R., \& Araújo, M. (2011). Topical antiinflammatory action of Caryocarvillosum oil (Aubl) Pers. Journal of Applied Pharmaceutical Science, 1(3), 62. 
Apenddix A. Equipment description

\section{Autoclave characteristics}

\subsection{Technical datasheet and marking}

Table A1 shows specifications such as brand, model, size and operating range of pressure and temperature.

Table A1. Autoclave characteristics.

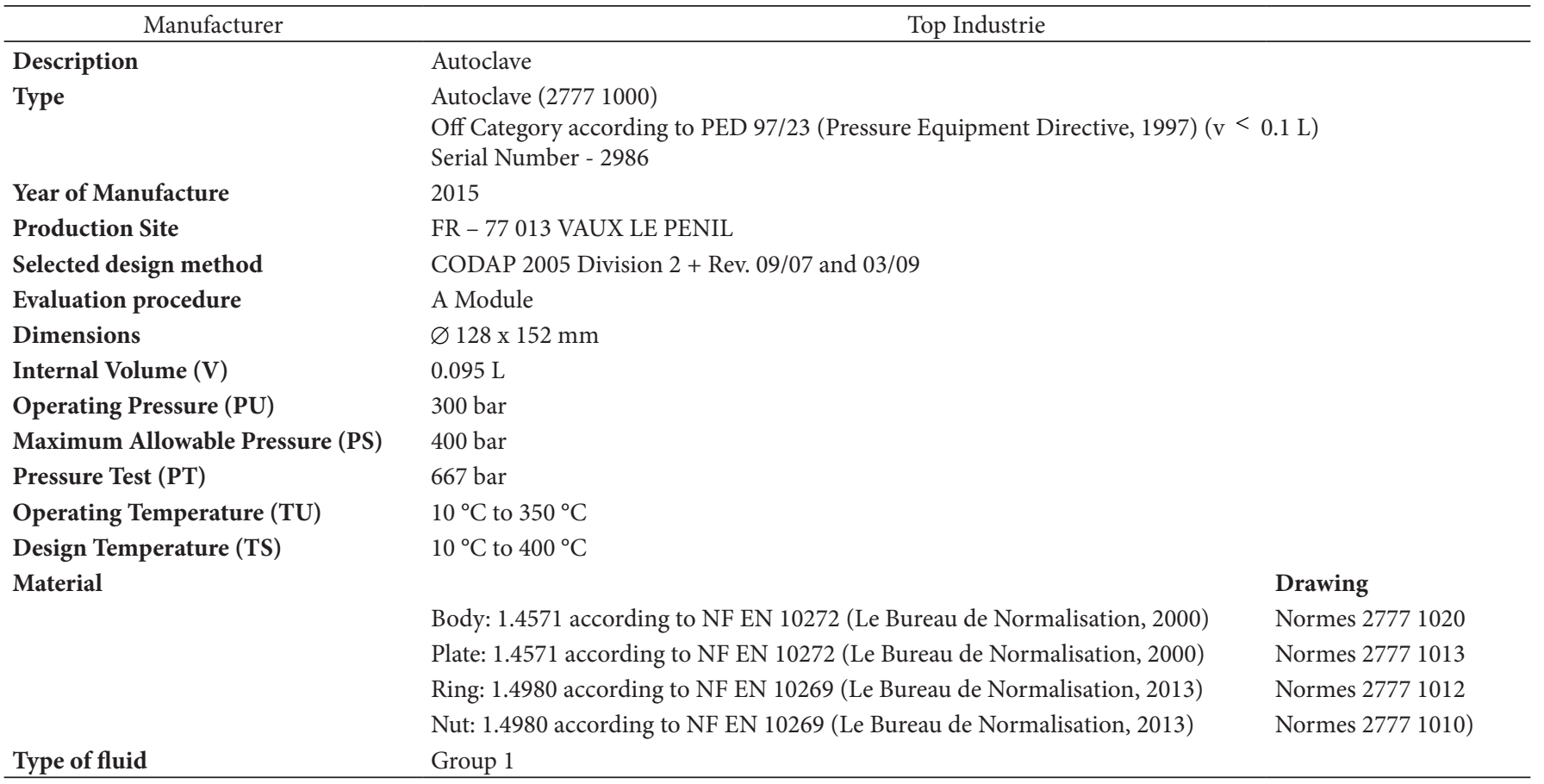

\subsection{General characteristics}

Figure A1 shows the autoclave in its structural frame coupled to the gas supply system and stirrer with water for its cooling system. Table A2 shows the dimensions of the structure with the autoclave.

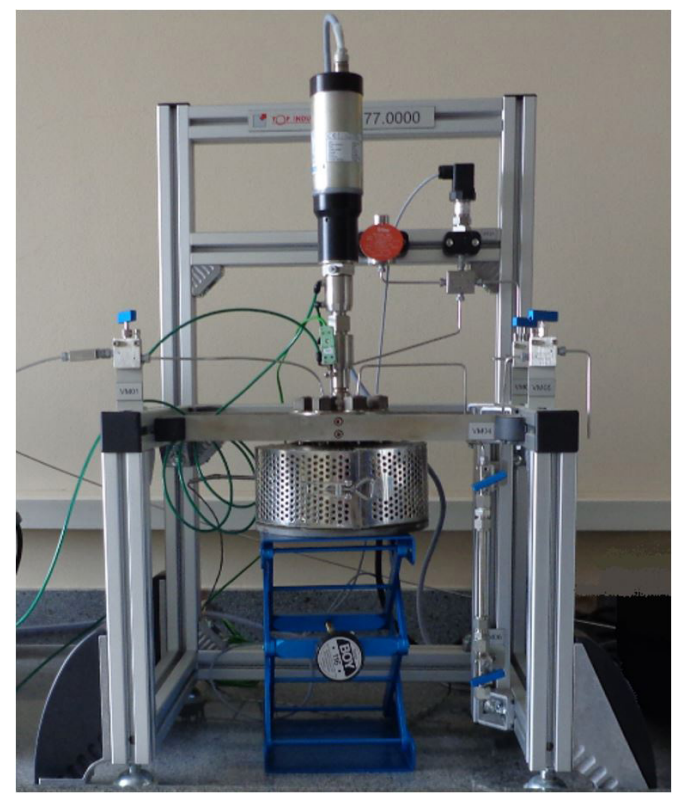

Figure A1. Frame with autoclave. 
Table A2. Measures of the frame with autoclave.

\begin{tabular}{ccc}
\hline & Magnitude & Approximatesize \\
\hline Width $(\mathbf{m m})^{\star}$ & 51 \\
Height $(\mathbf{m m})$ & 85 \\
Depth $(\mathbf{m m})$ & 42 \\
\hline
\end{tabular}

${ }^{*}$ (not including the 4 ground fixing squares).

\section{Design}

\subsection{Control cabinet}

From the control cabinet (Figure A2), it's possible to do: i. reading and regulation of the stirring speed; ii. temperature reading and regulation; iii. pressure reading; iv. flow measurement; v. emergency stop button.

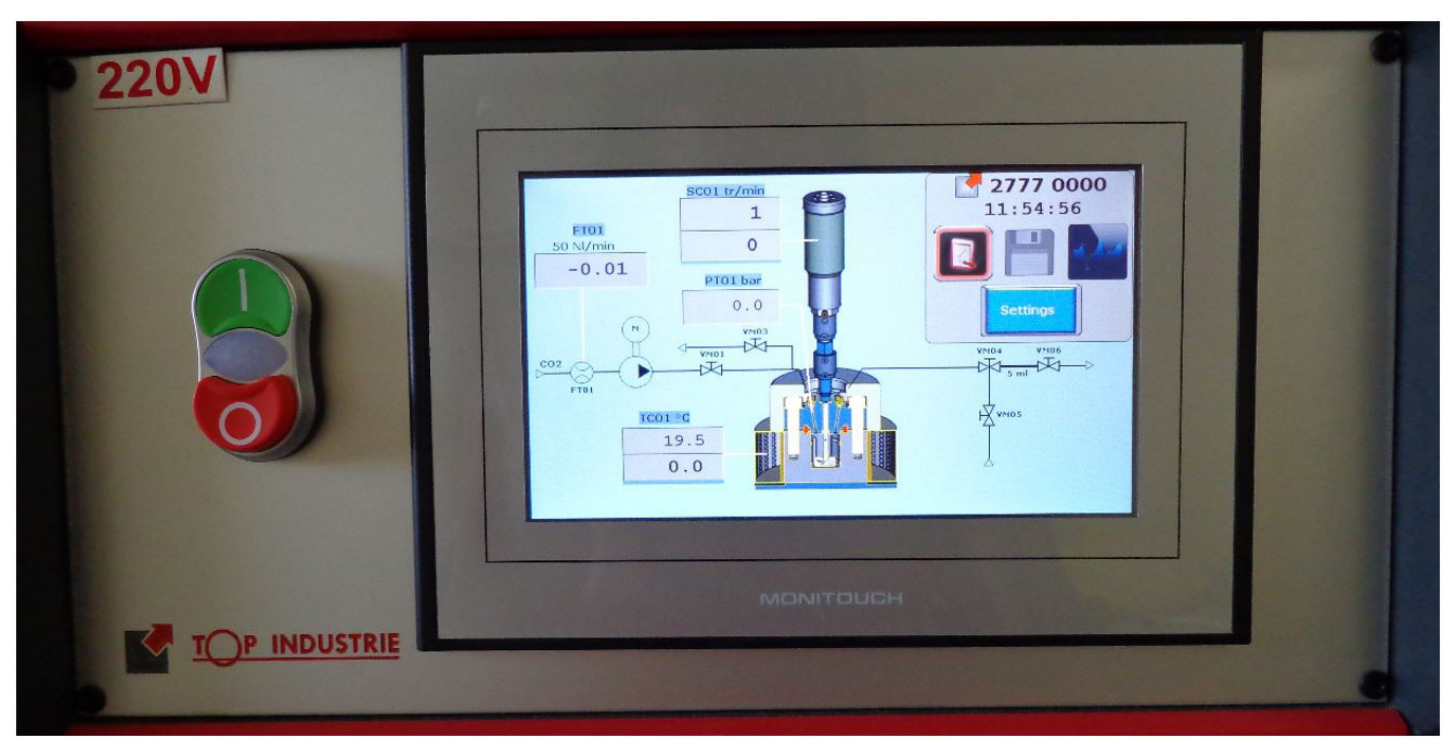

Figure A2. Control cabinet.

The control cabinet has the following features:

- Electrical supply: $230 \mathrm{VAC} / 50-60 \mathrm{~Hz} / 16 \mathrm{~A}$

- Maximum power: $3000 \mathrm{~W}$

\section{Assembly of the autoclave}

For correct assembly of the autoclave it is necessary to perform the following procedures:

- Check the property of the surfaces receiving the seal;

- Pull of the seal and clean it;

- Check the property of the threads on the body and the ring;

- Put if possible high temperature grease on the threads;

- The liquid should never completely fill the autoclave;

- Close the autoclave and tighten with the torque wrench showed in Figure A3 (Facom/nS.306A100 + extension S.210 + socket Hex $24 \mathrm{~mm} \mathrm{S.24H}$ ), in cross with tightening torque 20 N.m, then tightening torque 50 N.m (see Figure A4 for the detail of tightening in cross);

- Make if possible a tightness test at room temperature;

- Mount the insulating mantle on the top of the autoclave. 


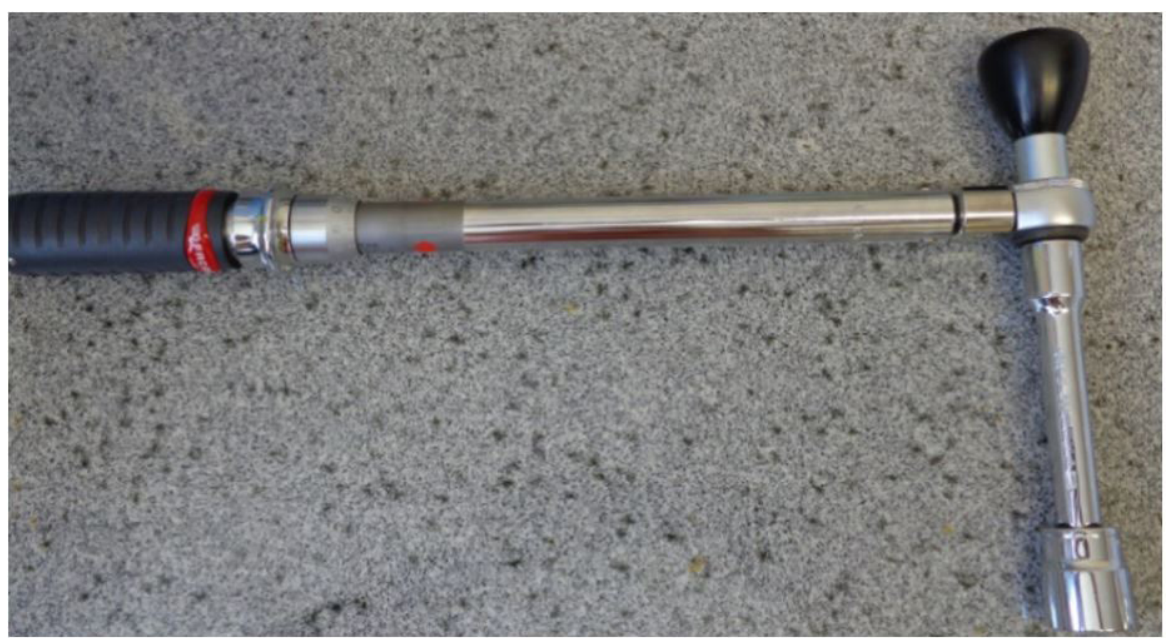

Figure A3. Torque wrench to close the autoclave.

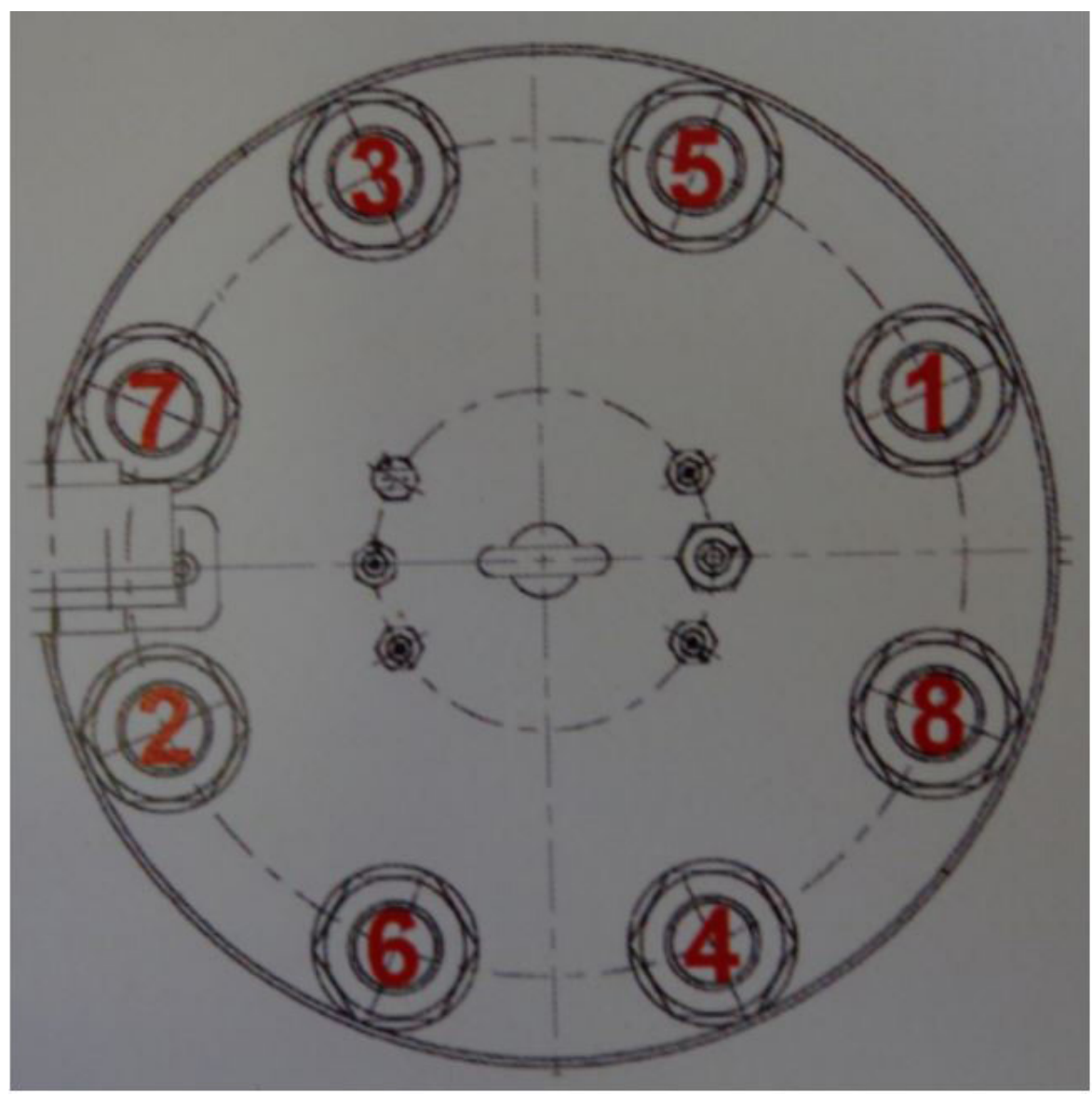

Figure A4. Detail of tightening in cross to correctly close the autoclave.

Observation: Never scratch contact surfaces from body or plate with a metal object, above all the effective cover area of gaskets. Never loosen or tighten up connections under pressure.

\section{Operating of the autoclave and control cabinet - Standard Operating Procedures (SOP'S)}

\subsection{Detailsofthe autoclave}

The Figure A5 shows the location of the pressure transmitter, the safety head and disc, the manual valves, the mechanical boy and the floor fixing squares. 


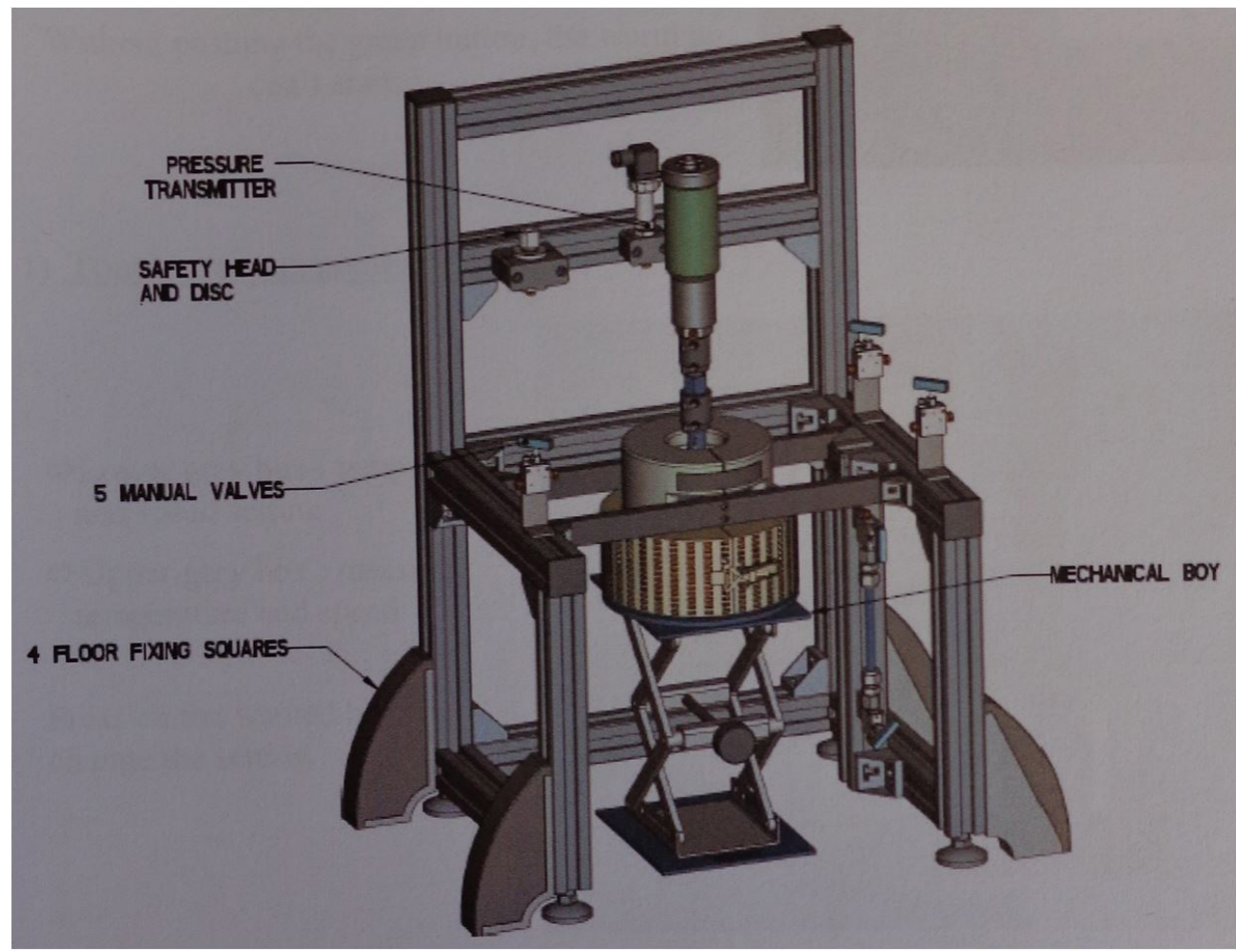

Figure A5. Details of the autoclave.

\subsection{Use of the control cabinet}

To use the control cabinet is required:i. powering of box by the master switch on the rear side (Figure A6.a); ii. start of the general by the green button "I" (Figure A6.b) without pushing the green button, the warm up can't start.

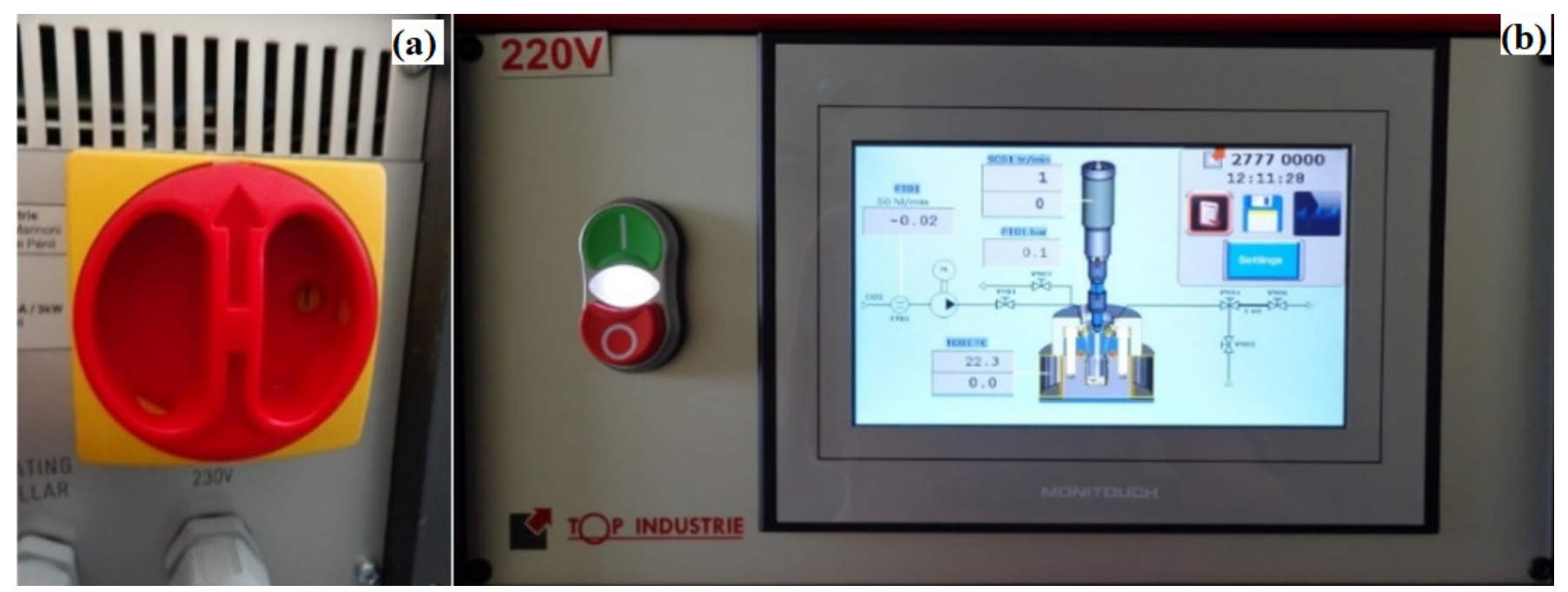

Figure A6. Control cabinet bottom (a) and front part (b).

\section{Touchscreen general screen}

The screen presents two main boxes for controlling of temperature and speed (Figure A7):

- Upper-grey box: measured temperature and speed. It's necessary to press on the wanted box no change the settings ("A.1");

- Lower grey box: temperature and speed setting (“A.2"). 


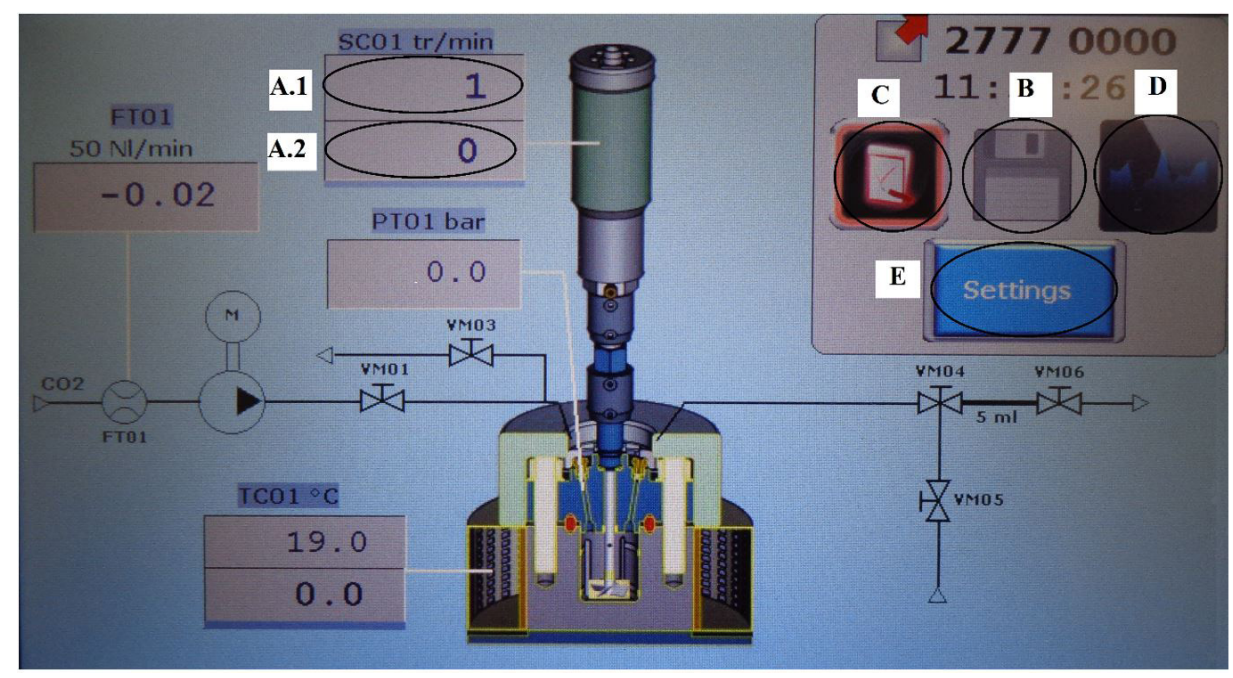

Figure A7. Touchscreen cabinet control.

Notes:

- To save the data, insert the USB key before the beginning of test to begin the recording of the test data (USB connection beside the box) - No data storage without USB key.

- Press on "B" (Figure A8) to start the recording of the temperature value;

- Press on "C" (Figure A8) to go to the "Warring screen";

- Press on "D" (Figure A8) to go to the "Curves screen".

\section{Setting screen}

Press on the "Settings" (Figure A8 - "E”) on the general screen:

- Press on the wanted box to have access to the HOUR screen (Figure A8 - "A");

- Modify the values with the boxes “+” and “-”, then validate on "B" and go back to the general screen by pressing on " $\mathrm{C}$ " (Figure A8).

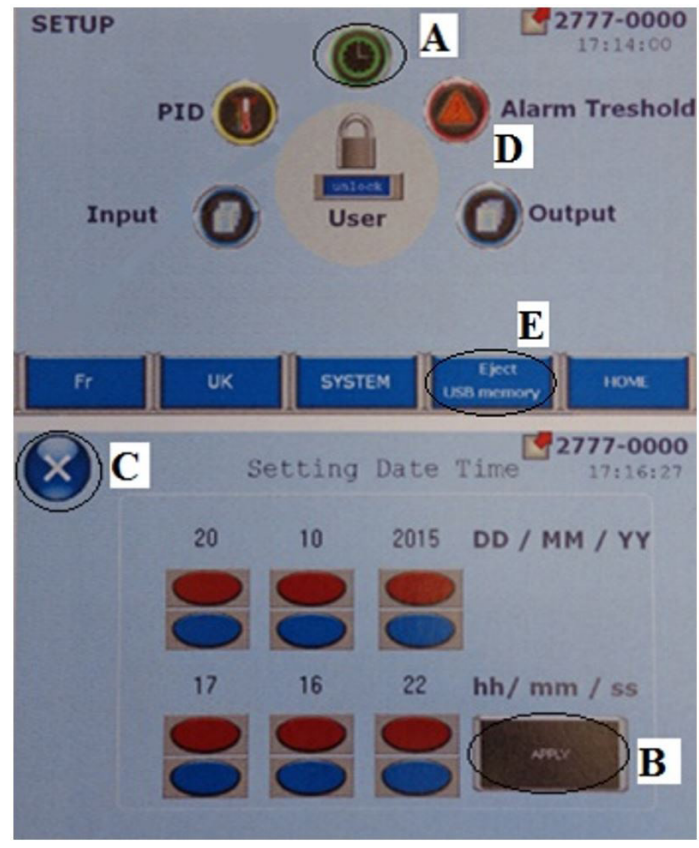

Figure A8. Modifying some settings. 


\section{Curves screen}

To go to curved screen is necessary to press the "D" icon (Figure A8).

- In the graphic boxes press on the icons "A" for 30 seconds, return to box and press on "B" for 5 seconds and return (Figure A9);

- Press the icon "Graph return" - "C" (Figure A9) to return at real-time;

- To change the scale of the Min or Max values: i. press on the value to change; ii. enter the new value on the keyboard; iii.validate by "OK".

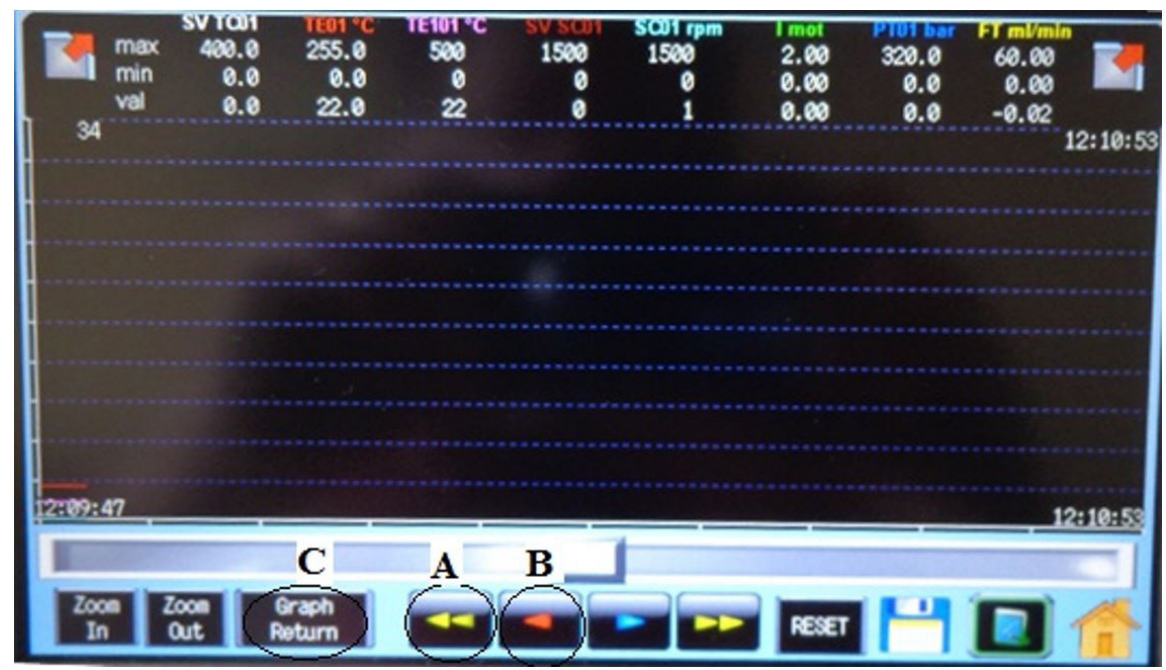

Figure A9. Curves screen.

Ejection of the USB key at the end of the test to get back the test curves

- Press on "Eject USB Memory" (Figure A8 - "E") and wait for the flickering of the paving stone.

- Storage of the data in the file DA T0000\SAMPLESISMP0000.csv

Note: the ejection of the USB key stops the posting of the curves on the screen

\section{Warning screen}

Press on "C" (Figure A8) to reach the screen. In this screen (Figure A10) you see information about alarm, alarm list, hours of start hour of ending. If the hour of ending is not written, the alarm is still continuing.

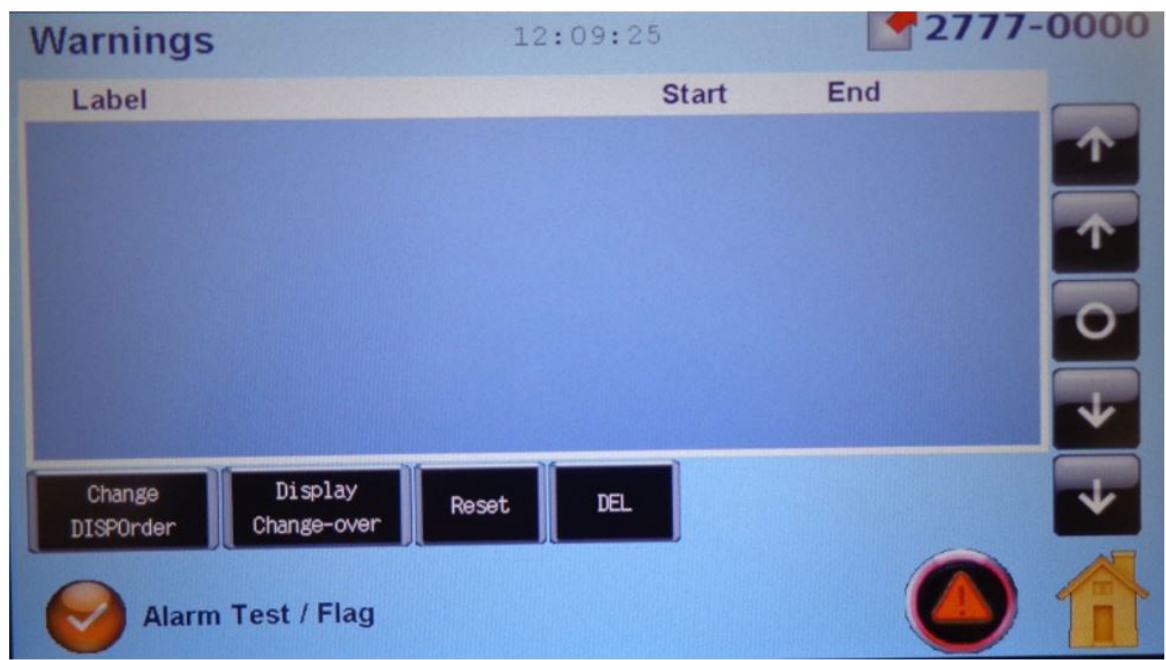

Figure A10. Warning screen. 


\section{Alarm threshold}

To access this function press on the settings screen (Figure A8 - "D") to reach this screen (Figure A11).

In this screen you can put alarm on different temperatures (right box in green) and measured temperatures (left box in blue).

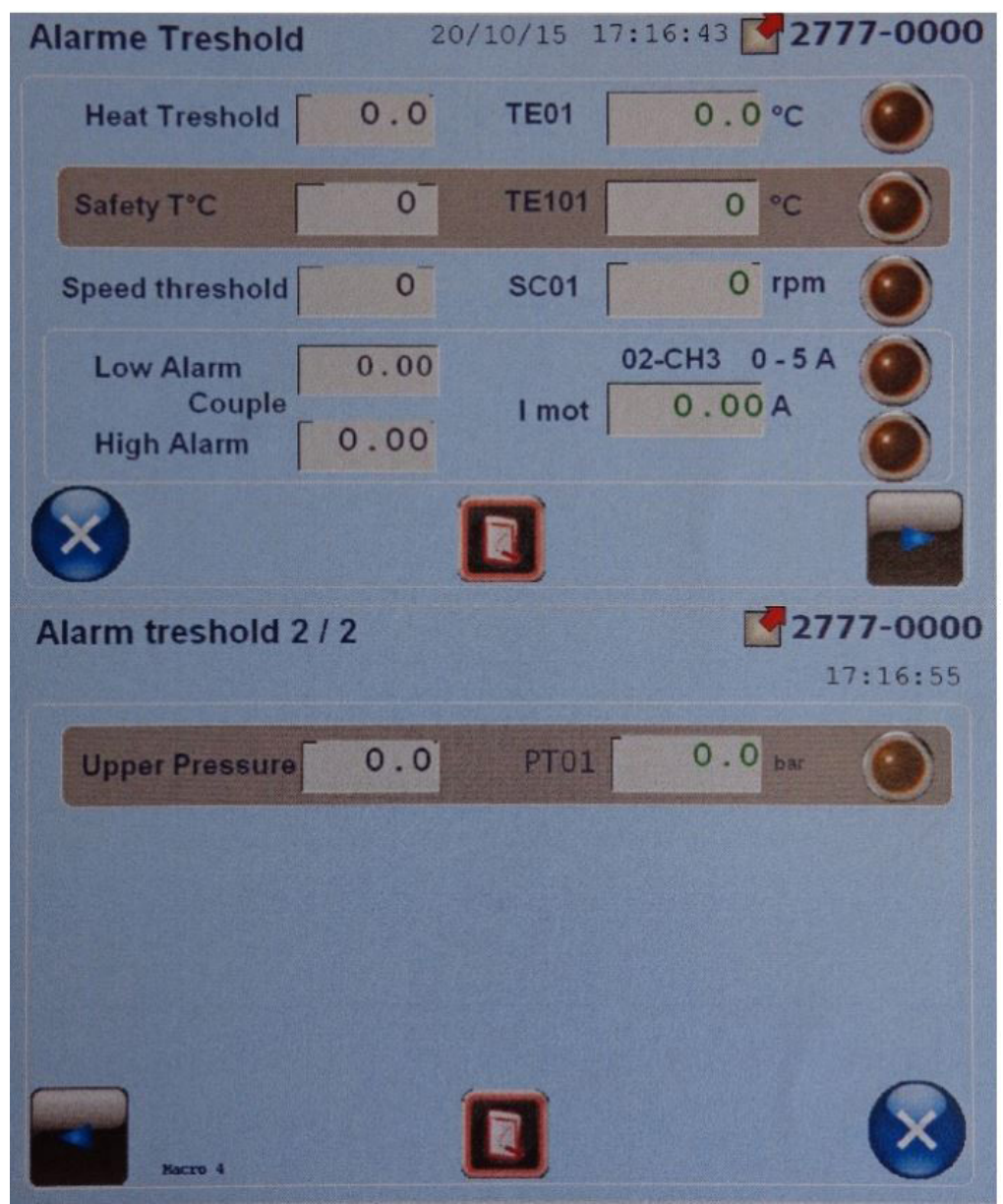

Figure A11. Alarm Threshold.

\section{Maintenance}

\subsection{Principles for high pressure parts}

- Pipe connections:

- Make sure that the connection is equivalent to the desired pressure;

- Increase pressure by stages and check the mechanical resistance;

- Never look for a leak using the hands;

- Never stand in front of a connection which has just been made;

- All connections shall be tested at maximum operating pressure before normal operation.

- Put a plug on all openings not used (circuit cleanliness).

- All used connections shall be referenced showing the operating pressure.

- List the internal connections;

- All connecting capillary tubes shall be fitted with a whiplash prevention system. 


\subsection{Autoclave 27771000}

Before carrying out maintenance, each time check that appliance is at ambient temperature and zero pressure using the pressure and temperature sensors located on the appliance.

\section{Annual preventive maintenance}

- Check the inside and outside parts under pressure to look for any damage or signs of corrosion.

- Check the safety organ (we recommend to change the safety disc).

- Check the pressure transmitter and the temperature measure loop.

\section{Corrective maintenance}

- Check the gasket faces in the autoclave in the event of a leak, and stripe impose a machining repairing.

\subsection{Maintenance expected for spare parts:}

The designation, size, supplier and use of spare parts are shown in the Table A3.

Table A3. Spare parts.

\begin{tabular}{|c|c|c|c|c|}
\hline Unit & Designation & $\mathrm{P} / \mathrm{N}$ & Supplier & Use \\
\hline 2 & O-ring viton & $\varnothing 10.82 \times 1.78$ & Sephat or equiv. & Stirrer internal \\
\hline 2 & O-ring viton & $\varnothing 14 \times 1.78$ & Sephat or equiv. & Stirrer internal \\
\hline 3 & Bearing & $60401401192 \mathrm{~N}$ & TOP INDUSTRIE & Stirrer internal \\
\hline 2 & O-ring & 26592005 & TOP INDUSTRIE & Stirrer/autoclave \\
\hline 2 & Plate seal & $\begin{array}{l}\text { R } 18 \text { OCTOGONAL } \\
\text {-POUR BRIDE RT }\end{array}$ & DELTA FLUIDE & Autoclave seal \\
\hline
\end{tabular}

\subsection{Stirrer series 6180100}

\section{Bearings}

- If the stirrer becomes noisy and/or vibrates, the bearings must be changed;

- If the noise and/or the vibrations persist, the stirrer must be returned to our after-sales service;

- The transversal groove on the bearing must not be in contact with the encapsulation.

Monthly preventive tightness maintenance

- O-ring seal marker 8: if the 'O' ring seal marker 8 is faulty, the gas leak will be canalized into the leak hole of the distance sleeve marker 2 (Figure A12). Use a bubbling product (water and soap) to control whether the O-ring is perfectly thight/fitting;

- Seal (between part marker 2 and flat bottom): use a bubbling product (water and soap) directly on the connection (M20 x 150) between the stirrer and the autoclave head (Figure A12);

- Motor, ball bearing, magnetic coupling: no maintenance. If a problem appears, the complete stirrer must be returned to our after-sales service.

\section{Annual preventive maintenance}

- Change the bearing and the O-ring;

- Check the magnetic coupling efficiency;

- For maximum protection, the stirrers are designed so that the compressed air or electric motor blocks and not the magnetic coupling. 


\section{Corrective maintenance}

- If the stirrer becomes too noisy or vibrate, change the bearings;

- If the noise still exists, the stirrer must be returned to the SAV service for repairing.

Corrosion: The parts that are in contact with the fluid are made of stainless steel 1.4404 and 1.4980 . No traces of corrosion should appear. If this were to happen, it would be because the equipment was not suitable for application. It is dangerous and forbidden to use a stirrer under such conditions.

\section{Dismounting}

- Disconnect the stirrer from its power or energy supply;

- Disconnect the stirrer from the autoclave;

- Unscrew and remove the screw marker 6 (Figure A12);

- Unscrew the motor-distance sleeve (marker 12) while holding the body (marker 2) and the ring marker 9; apply pressure slightly in order to defeat the attraction of the magnetic field (Figure A12);

- Unscrew the ring number 9 while holding the body marker 12 (Figure A12);

- Pull the upper body marker 11 towards the top. Remove the stirring module;

- The central axis marker 9 (Figure A12) may now be removed from its housing;

- The bearings (marker 1) and the O-ring (marker 8) are now accessible for checking or replacement (Figure A12).
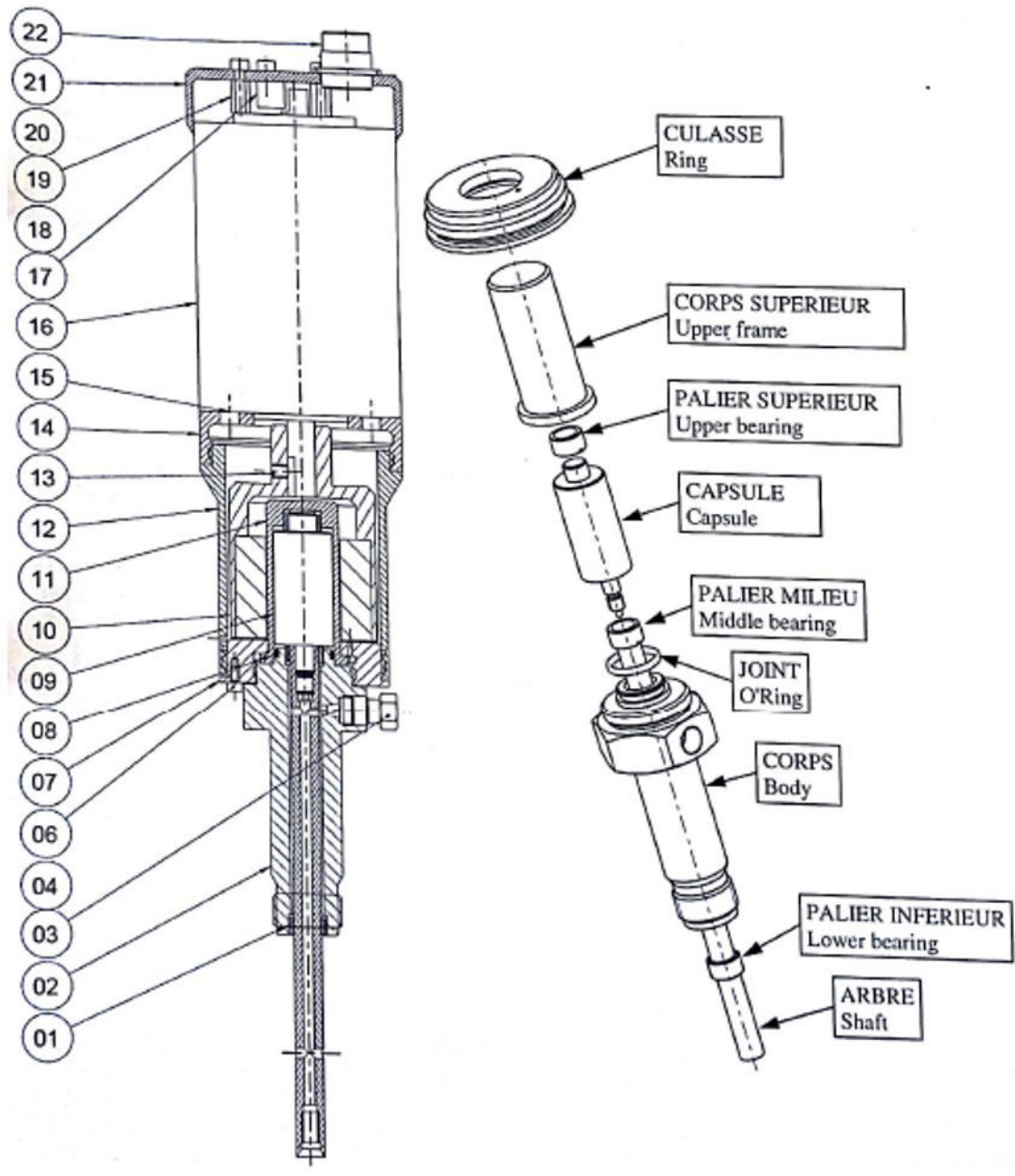

Figure A12. Stirrer's parts. 


\section{Assembly}

After having thoroughly cleaned all the parts and having, if necessary, proceeded to replace the bearings marker 1 and the seal marker 8 (Figure A12), reassemble as follows:

- Slide the central axis marker 9 (Figure A12) into its housing and manually, make sure that the it rotates correctly;

- Put marker 11 (Figure A12) back into place by forcing slightly. If permitted, it is advisable to apply a drop of lubricant such as vaseline in order to make sliding easier on the joint;

- Manually screw back on the part marker 12 (Figure A12). Tighten until metal against metal contact is obtained;

- Rescrew the screw marker 6 (Figure A12).

Note: for the $\mathrm{P} / \mathrm{N}$ of the bearings and O'ring, see the autoclave part list.

\subsection{Settings of parameters on the touchscreen:}

Accessible by pressing on the button Settings (Figure A8 - "E"). The settings are locked by default ("lock"). To unlock, press on the 'unlock' box (Figure A13 - "A"); when the next screen appears, enter the password (TOP) and validate by "Enter" and press on "B" (Figure A13) to go back to the Setting screen.

Note: Any parameter modification must be made only by qualified person.

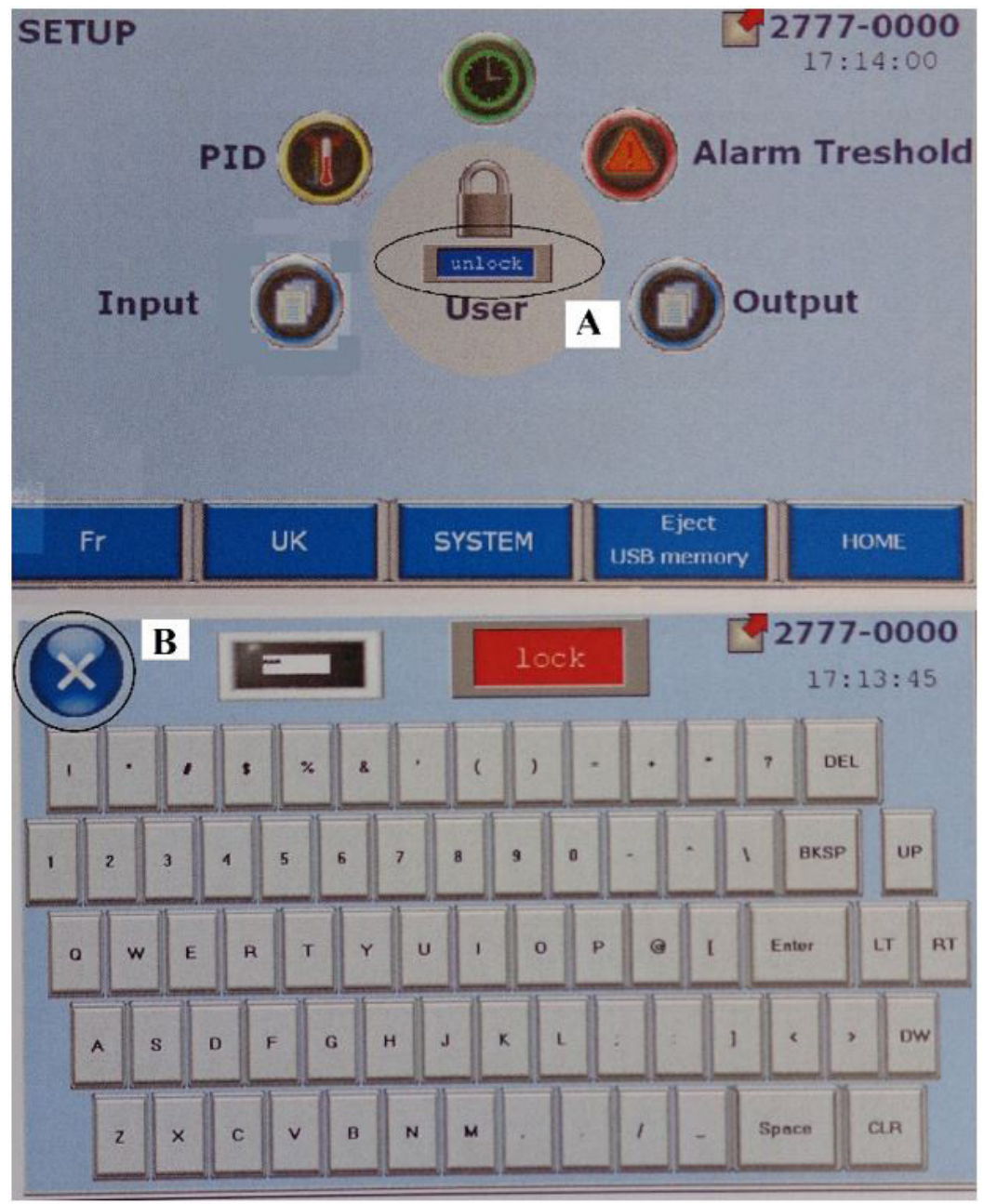

Figure A13. Unlocking the settings. 


\section{Technical data}

Electrical characteristics

Power supply voltage Vcc (tolerated ripple $<5 \%$ 10 to 60 DVC

Permanent output current $\mathrm{I}_{\mathrm{m}}$ $10 \mathrm{~A}$

The motor current is limited to $I_{\text {mom }}+I_{\text {boost }}$ for $500 \mathrm{~ms}$ then to $I_{\text {mom }}$ for 10 s (motor overload) before being cut (motor locks up). Any current return under the limitation resets the detection time

Commutation frequency. $20 \mathrm{KHz}$

Inputs

SET VALUE: Set point value (terminals 1, 2 and 3) $.0 /+10 \mathrm{DVC}\left(\mathrm{R}_{\mathrm{t}}>10 \mathrm{~K} \Omega\right)$

ENABLE: active when the contact is closed (terminals 4 and 8) Dry contact

CW/CCW: open contact: clockwise (terminals5 and 8) contactclosed:Counterclockwise direction.

\section{Dry contact}

In the event of an inversion of the rotation direction with a non-zero speed, the servo amplifier waits until the current is cancelled in the motor before reversing the rotation direction.

Outputs

I MOT: Image with $I_{\text {mom }}$ current voltage during nominal operation (terminals $9 \& 12$ )

This output is protected against short-circuits. $. .0 /+10 \mathrm{VDC}\left(\mathrm{R}_{0}=100 \Omega\right)$

Proportionality factor.

MONITOR: Image with $\mathrm{I}_{\text {mom }}$ and $\mathrm{I}_{\text {boost }}$ current voltages during settings (terminals 10 \& 12)

This output is protected against short-circuits. $.0 /+5 \mathrm{VDC}\left(\mathrm{R}_{0}=100 \Omega\right)$

Proportionality factor. $1 \mathrm{~V} / 2 \mathrm{~A}$

READY: Message for monitoring the state of card (terminals 11 and 12)

Open collector not protected from the short-circuits ..max. 30 VDC $\left(\mathrm{I}_{\mathrm{t}}<20 \mathrm{~mA}\right)$

Output voltage

+ 10V: Auxiliary voltage (terminals $1 \& 3$ ) .10 VDC, max. $20 \mathrm{~mA}$

Protected against short-circuits and overloads

Setting Push buttons

OK: Validation or setting mode input/output

+ : Increase of parameterisable values

+ : Reduction of parameterisable values

LED indicador

Green LED Presence of voltage

Orange LED Steady. .Clockwise rotation direction

Orange flashing LED Counterclockwise rotation direction

Red LED. .Fault

Temperature / Humidity

Operation .0 to $+45^{\circ} \mathrm{C}$ 
Relative humidity. .20 to $80 \%$ non-condensed

Mechanical characteristics

Weight approximately $220 \mathrm{~g}$

Dimensions... $102 \times 100 \times 32$ (or $3 U$ frame)

Mounting plate. for M4 screw

\section{Connections}

Terminals with screws

"Power"(4 poles), "Signal”(12 poles)

Power step.

$.5 .08 \mathrm{~mm}$

Suitable for sections of wire.

0.5 to $2.5 \mathrm{~mm}^{2}$

Signal step.

$.3 .81 \mathrm{~mm}$

Suitable for sections of wire.

0.14 to $1.5 \mathrm{~mm}^{2}$

The Table A4 shows the parts list as well as their material and suppliers.

Table A4. Parts list.

\begin{tabular}{|c|c|c|c|c|c|c|c|}
\hline & $\mathrm{Nb}$ & Designation & Material & Ref. Top & Ind. & Ref. Supplier & Supplier \\
\hline 01 & 1 & $\begin{array}{l}\text { Magnetic stitrrer } \\
30 \text { N.cm }\end{array}$ & & 6160100 & $\mathrm{D}$ & & Top Industrie \\
\hline 02 & 2 & Water Jacket & & 6049900 & $\mathrm{C}$ & & Top Industrie \\
\hline 03 & 1 & stirrer adapter & 1.4404 & 2691004 & & & Top Industrie \\
\hline 04 & 1 & Stirrer seal & Viton & & & $\varnothing 10.82 \times 1.78$ & Sephat \\
\hline 05 & 4 & 1/8" HP Screw & & 9200100 & & & Top Industrie \\
\hline 06 & 4 & 1/8" HP Ferrule & & 9200200 & & & Top Industrie \\
\hline 07 & 1 & Mantile insulator & & 27771007 & A & & Top Industrie \\
\hline 08 & 1 & Stirrer seal washer & 1.4404 & 27771008 & & & Top Industrie \\
\hline 09 & 1 & Stirrer seal & NIKEL & 26592005 & $\mathrm{~A}$ & & Top Industrie \\
\hline 10 & 8 & Nut - M16 x 1.5 & 1.4980 & 27771010 & & & Top Industrie \\
\hline 11 & 8 & Washer M16 & INCO 718 & $\begin{array}{c}6920216 \text { INCO } \\
718\end{array}$ & & & Top Industrie \\
\hline 12 & 8 & Stud - M16 & 1.4980 & 27771012 & & & Top Industrie \\
\hline 13 & 1 & Flat bottom & 1.4571 & 27771013 & & & Top Industrie \\
\hline 14 & 1 & Flat seal & Stainless stell & & & R 18 Octogonal RTJ flange & Top Industrie \\
\hline 15 & 2 & Lower bearing & $1192 \mathrm{~N}$ & 6040140 & B & & Top Industrie \\
\hline 16 & 1 & $\begin{array}{c}\text { Hc M3 X } 8 \mathrm{~mm} \\
\text { Screw }\end{array}$ & & & & Hc M3 X 8 & Top Industrie \\
\hline 17 & 1 & DB baffle bar & 1.4404 & $65300 \mathrm{DB} 00$ & & & Top Industrie \\
\hline 18 & 1 & Stirring shaft & 1.4404 & 27771018 & & & Top Industrie \\
\hline \multirow[t]{3}{*}{19} & 1 & $\varnothing 20$ Impeller & & 608019400 & & & Top Industrie \\
\hline & 1 & Body impeller & 1.4404 & 608019401 & & & Top Industrie \\
\hline & 8 & bar & 1.4404 & 608019402 & & & Top Industrie \\
\hline 20 & 1 & Body & 1.4571 & 27771020 & & & Top Industrie \\
\hline 21 & 1 & Heating collar & & 27771021 & & & Top Industrie \\
\hline 22 & 2 & $\begin{array}{c}\text { FHc M8 x } 25 \text { mm } \\
\text { (high temperature) } \\
\text { Screw }\end{array}$ & Stainless stell & & & Fhc MB x 25 & BAFA \\
\hline 23 & 1 & Botton insulator & Mica silicone & 27771023 & A & & Top Industrie \\
\hline 24 & 1 & $\begin{array}{c}\text { Thermocouple } \\
\mathrm{K} \varnothing 1.5 \text { - L } 200 \mathrm{~mm}\end{array}$ & & & & TKA 15 x 20 HMP & Erciat \\
\hline 25 & 1 & Thermowell & 1.4404 & 27771023 & & & Top Industrie \\
\hline
\end{tabular}


Costa et al.

Table A4. Continued...

\begin{tabular}{|c|c|c|c|c|c|c|c|}
\hline & $\mathrm{Nb}$ & Designation & Material & Ref. Top & Ind. & Ref. Supplier & Supplier \\
\hline 26 & \multicolumn{7}{|c|}{ Pieces de rechance } \\
\hline 27 & 2 & Stirrer seal & Viton & & & $\varnothing 10.82 \times 1.78$ & Sephat or equiv. \\
\hline 28 & 2 & Stirrer seal & Niquel & 26592005 & A & & Top Industrie \\
\hline 29 & 9 & Botton flat seal & Inox & & & R 18 Octogonal RTJ flange & Delta Fluide \\
\hline 30 & 3 & Lower bearing & $1192 \mathrm{~N}$ & 6040140 & 8 & & Top Industrie \\
\hline 31 & 1 & $\begin{array}{l}\text { Torque key } \\
(50 \text { N.m) }\end{array}$ & & & & S.308 A 100 & Facom \\
\hline 33 & 1 & $\begin{array}{l}\text { Hexagonal socket } \\
\text { M } 16 \text { / HEX } 24 \mathrm{~mm}\end{array}$ & & & & S. $24 \mathrm{H}$ & Facom \\
\hline 34 & 3 & Lower bearing & Graphite & $6040140 \mathrm{GR}$ & B & & Top Industrie \\
\hline 35 & & $\begin{array}{c}\text { O'ring } \\
\text { (internal stirrer) }\end{array}$ & Viton & & & $\varnothing 14 \times 1.78$ & Sephat or equiv. \\
\hline
\end{tabular}

